Article

\title{
Engaging Southwestern Tribes in Sustainable Water Resources Topics and Management
}

\author{
Karletta Chief ${ }^{1, *}$, Alison Meadow ${ }^{2}$ and Kyle Whyte ${ }^{3}$ \\ 1 Department of Soil, Water, and Environmental Sciences, University of Arizona, Tucson, AZ 85721, USA \\ 2 Center for Climate Adapation and Science Solutions, University of Arizona, Tucson, AZ 85721, USA; \\ meadow@email.arizona.edu \\ 3 Department of Philosophy and Department of Community Sustainability, Michigan State University, \\ East Lansing, MI 48824-1032, USA; kwhyte@msu.edu \\ * Correspondence: kchief@email.arizona.edu; Tel.: +1-520-626-5598
}

Academic Editors: Eylon Shamir, Sharon B. Megdal and Susanna Eden

Received: 5 April 2016; Accepted: 13 July 2016; Published: 18 August 2016

\begin{abstract}
Indigenous peoples in North America have a long history of understanding their societies as having an intimate relationship with their physical environments. Their cultures, traditions, and identities are based on the ecosystems and sacred places that shape their world. Their respect for their ancestors and 'Mother Earth' speaks of unique value and knowledge systems different than the value and knowledge systems of the dominant United States settler society. The value and knowledge systems of each indigenous and non-indigenous community are different but collide when water resources are endangered. One of the challenges that face indigenous people regarding the management of water relates to their opposition to the commodification of water for availability to select individuals. External researchers seeking to work with indigenous peoples on water research or management must learn how to design research or water management projects that respect indigenous cultural contexts, histories of interactions with settler governments and researchers, and the current socio-economic and political situations in which indigenous peoples are embedded. They should pay particular attention to the process of collaborating on water resource topics and management with and among indigenous communities while integrating Western and indigenous sciences in ways that are beneficial to both knowledge systems. The objectives of this paper are to (1) to provide an overview of the context of current indigenous water management issues, especially for the U.S. federally recognized tribes in the Southwestern United States; (2) to synthesize approaches to engage indigenous persons, communities, and governments on water resources topics and management; and (3) to compare the successes of engaging Southwestern tribes in five examples to highlight some significant activities for collaborating with tribes on water resources research and management. In discussing the engagement approaches of these five selected cases, we considered the four "simple rules" of tribal research, which are to ask about ethics, do more listening, follow tribal research protocols, and give back to the community. For the five select cases of collaboration involving Southwestern tribes, the success of external researchers with the tribes involved comprehensive engagement of diverse tribal audience from grassroots level to central tribal government, tribal oversight, on-going dialogue, transparency of data, and reporting back. There is a strong recognition of the importance of engaging tribal participants in water management discussions particularly with pressing impacts of drought, climate change, and mining and defining water rights.
\end{abstract}

Keywords: indigenous; tribes; Native Americans; stakeholder engagement 


\section{Introduction}

Indigenous people often understand themselves as having an intimate relationship to the environment and cosmos in which they consider every element and species to have life and to be sacred. Some indigenous people believe that human and nonhuman individuals come from the earth and the ability to reach harmony among individuals is dependent on being a steward of the natural environment by giving back more than what is taken. To many indigenous people, water is life and water is sacred. Water is part of religious and cultural practices for purification, prayers, and various ceremonies. Water is also part of indigenous identities and origin stories; for a Diné-specific example, Diné deities include "Born-for-water" and Diné clans include "Big-water", "Near-the-water" and many other water-based clans. To indigenous people, the use of water is integrated with respect for the water as a living entity that gives life and supports the health, integrity, and character of an individual. Similar relations exist across North America. For Anishinaabe people (Ojibwe, Odawa, Potawatomi, among others), the value of water arises from the creation story in which water is considered to play the role of a source and supporter of life. Water mediates interactions among many living beings on the earth and is considered a relative with responsibilities to give and support life. Bodies of water are considered to have their own unique personalities. Humans have special responsibilities to respect and care for water and to encourage its life-giving force. Ceremonies are organized to ensure people renew their connections to water $[1,2]$. The sacredness of water represents a cross-cutting way Southwestern tribes approach their relationship to the environment.

One hundred and eighty-two federally recognized tribes have tribal lands in the six states of the Southwestern United States: Arizona, New Mexico, Colorado, Utah, Nevada, and California [3]. Tribal land holdings range from small rancherias, colonies, and reservations, such as the 20-acre reservation of the Augustine Band of Cahuilla Indians in California to the 27,413 square-mile reservation of the Navajo Nation located across Arizona, Utah, and New Mexico. Tribal lands are in rural and urban areas, for example, the Fort McDermitt Paiute-Shoshone Reservation lies within the rural Nevada-Oregon high deserts and the Las Vegas Tribe of Paiute Indians of the Las Vegas Indian Colony is located in the heart of the Las Vegas metropolitan area. Tribal economies vary widely including ranching, agriculture, mining, gaming, tourism, retail, and various other industries. Tribal lands span diverse ecosystems and climatic regions with highly varied precipitation and temperature patterns from arid deserts to fertile valleys as well as coastal and mountainous terrains. The Southwest is home to seven of the largest tribes and five of the largest Indian reservations. Many cities in the Southwest have large and diverse tribal communities that have organized centers and other institutions that provide health and other services, legal advocacy, and support of cultural continuance. California has the largest percentage of citizens (14\%) who identify as American Indian and Alaska Native alone or in combination with another race (followed by Oklahoma, Arizona, Texas, and New York) [4] and 33\% of the state of Arizona is tribal land. Tribes in the Southwest are diverse in their languages, traditions, beliefs, and geographic settings.

The legal, political, and cultural frameworks surrounding water in the U.S., which often treat water as a commodity that can be transferred and sold [5], can cause dissonance and challenges for indigenous communities who wish to assert their legal and political rights to water through their own cultural frameworks that treat water as sacred. There are at least four overarching challenges that face tribes regarding this dissonance, some of which are issues primarily for U.S. federally recognized tribes and others that are concerns for indigenous peoples more broadly. First, water laws governing the Western U.S. are based upon the concept of prior appropriation, or "first in time, first in right" and give priority to those water users presumed to have first put the water to beneficial use [5,6]. One specific barrier created by the idea of prior appropriation is that only federally recognized tribes are given this Westernized right [7]. For tribes that have occupied ancestral lands for thousands of years through complex cultural and political systems, which often emphasize kin, clan, and spiritual relationships, the concept of divvying up waters to tribal governments or to individual persons, settler or indigenous, is difficult to accept. Moreover, recognition of water rights for cultural and ceremonial practices 
is not always considered or part of the legal processes of water quantification [8]. Secondly, water contamination can mean two very different things to indigenous and non-indigenous communities. When water is contaminated, the contamination can be emotionally devastating and traumatic for indigenous peoples, particularly when the water is connected to sacred sites, religious concepts, and subsistence activities [9-13]. Third, partly as a result of the legal and political challenges discussed above, indigenous communities have often been excluded from negotiations and discussions about water management practices. Often, indigenous people are not at the table when water management decisions are made and data are not available in transparent or accessible ways [14,15]. Finally, the fourth overarching challenge-which certainly is influenced by and influences the other three-is that traditional knowledge(s) (TK) related to the management of water have often not been given equal standing or respect in U.S., Canadian, and other Western water management frameworks [14,15]. Traditional knowledge is local knowledge which have been gathered and refined over hundreds of years, passed down from generation to generation through particular cultural, economic, and spiritual practices and is part of the fabric of indigenous communities [16]. Traditional knowledges can be used to structure and guide scientific research, corroborate environmental data collected using instruments, and offer options for resilient management practices for indigenous people $[17,18]$. In order to effectively engage tribes in water management topics, it is important to recognize these challenges and ways to address these challenges using culturally appropriate and tribal specific engagement.

The objectives of this paper are (1) to provide an overview of the context of current tribal water management issues, especially for U.S. federally recognized tribes in the Southwestern United States; (2) to synthesize approaches to engage tribal individuals, communities, and governments on water resources topics and management; and (3) to compare the success of engaging Southwestern tribes in five examples to highlight some significant activities for collaborating with tribes on water resources research and management.

\section{Context of Tribal Water Resources Management Issues}

\subsection{Indigenous Governance and Sovereignty}

The legal, political, and historical frameworks that govern tribes within the U.S. strongly influence the ways in which tribal water rights are allocated and the ways in which water is and can be managed by tribes. In the following section, we outline the key principles of federal Indian law and tribal water rights, especially ones that are relevant to U.S. federally recognized Southwestern tribes. In the United States, there are 567 federally recognized tribes and at least 34 state recognized tribes [3]. The former are sovereign nations in the eyes of the U.S. who maintain government-to-government relationships with the U.S. government. Tribal sovereignty refers to the principle of self-governance; in the context of federal-tribal relations it means that any rights not explicitly ceded through treaty making are assumed to remain under tribal control—such as rights to water, natural resources, and internal self-governance. However, that sovereignty is limited because tribes now exist within the borders of the U.S. and there are limits on tribal capacity to regulate non-tribal members living in their jurisdictions. Tribes are legally described as "domestic dependent nations," in a guardian-ward relationship with the federal government [19]. The domestic dependent nation status has led to the concept of the trust doctrine, which requires the federal government to act in the best interests of tribes [19]. It is important to note that, while legal principles hold that tribes are on equal footing with the federal government and the government must support their best interests, neither the government-to-government relationship or the trust doctrine have been consistently applied throughout the history of federal-tribal relationships. Although the Department of Interior, Bureau of Indian Affairs (BIA) is assigned to enact this trust responsibility and oversee tribal assets, the BIA acting on behalf of federally recognized tribes has mismanaged programs, lands, and natural resources, and often failed to act according to the best interest of tribes [20-23]. In recent decades, progress has been made in terms of tribal control of tribal resources, such as the 1975 Indian Self-Determination and 
Education Assistance Act and subsequent amendments (known informally as "638 contracts") which allow tribes to contract with the federal government to operate programs serving their tribal members and the Indian Gaming Regulatory Act of 1988, which can support natural resource management with gaming revenue.

As inherently sovereign nations, federally recognized tribes technically have the right, in the eyes of the U.S. federal government, to determine their own governing structures. Some tribes have maintained their traditional governments while other tribes have democratic Westernized tribal governments institutionalized by the U.S. government through the 1934 Indian Reorganization (Wheeler-Howard) Act [24]. For example, the Cochiti Pueblo in New Mexico maintains a traditional form of government, where the chief spiritual leader appoints the War Chief and Lieutenant War Chief, who are responsible for over-seeing and preserving the cultural and ceremonial calendar and the Governor and Lieutenant Governor, who carry out governmental affairs. On the other hand, the Ho-chunk Nation has a democratic election where candidates vying for President are elected based on popular vote. Tribes' abilities to control and manage natural resources are also affected by the ways in which land is held in their regions. Although reservation lands are controlled by tribal governments (and held in trust by the federal government), due to legislation such as the 1887 Dawes Act [25], some tribal lands have been allotted to individual owners, making them fee-simple lands controlled by individuals, not tribal governments. In some cases, reservations are "checkerboarded" with some tracts owned by tribal members or non-tribal members and others still under the control of tribal governments-making comprehensive natural resource management all the more challenging [26,27]. This is the case for the Cherokee Nation of Oklahoma where the tribal nation must manage their resources where there is significant non-tribal activity. It is also the case that within federally recognized, state recognized and unrecognized tribes, groups of tribal members continue their own "grassroots" water stewardship or management systems that are not recognized by any U.S. federal or state entity as self-determining entities. This initial use of the word "grassroots" is in quotes because sometimes these groups are exercising stewardship or management systems based on traditional knowledge that predates the U.S. or the era of federally recognized tribal governments. These groups, whether operating within federally recognized or unrecognized tribes, face the jurisdictional and governance challenges of not being respected as caretakers.

\subsection{Tribal Water Rights}

Federally recognized tribes have federally reserved water rights with a priority associated with the date their reservation was created. These rights were codified in the 1908 Winter's Doctrine [7]. Specifically, a tribe has rights to sufficient water to fulfill the purposes of its reservation, as defined by the U.S. government, such as agricultural production, and could not be lost due to non-use [28]. The McCarran Amendment [29] waived federal sovereign immunity in state water adjudications and allowed states to quantify federal reserved water rights including tribal reserved water rights in basin-wide adjudication, in which the courts assess and catalogue water rights contested in court. Tribes can also pursue negotiated water settlements bringing federal and non-tribal and tribal water users to the table to negotiate water rights [30].

In 1983, in Arizona v. California, tribal water rights were associated with the practicable irrigable acreage (PIA) policy, in which tribal water rights are quantified based on the amount of water needed to irrigate irrigable lands on the reservation [31,32]. PIA places limits on tribes insofar as only allocating water for agriculture, even though in some cases, tribes are not agriculturally based or not in a climate that necessarily supports agriculture on a large scale. In 2001, the Arizona Supreme Court ruled that PIA is not the only standard for determining water allocations. In Adjudication of All Rights to Use Water in the Gila River System and Source, the Court added the "homeland standard" for calculating the amount of water a tribe is entitled to, in recognition of the rights of tribal members to adequate water to live on reservations and not just for farming [33]. 
Tribes have been advocating for cultural uses through beneficial uses and water for the environment such as leveraging in-stream flow rights, minimum flow requirements, and Endangered Species Act. Rancier [8] analyzed 27 tribal water rights settlements and concluded that negotiated water rights allowed more flexibility to meet the needs of parties particularly for cultural water uses. Rancier [8] compared two tribal water settlements, The Snake River Water Rights Settlement ("Nez Perce Water Rights Settlements") and Truckee-Carson Pyramid Lake Water Rights Settlement Act and the Preliminary Settlement Agreement ("The Pyramid Lake Settlement") using a 28 point criteria to determine the success, strength, and weaknesses of the settlements [8,34]. Both of these tribes rely on fisheries for subsistence and cultural purposes and their settlements supported tribal fisheries listed under the Endangered Species Act. The Pyramid Lake Paiute Tribe (PLPT) used the Endangered Species Act to prevent further reduction of instream flows in the Truckee River System where overuse by agricultural activities resulted in fish floundering in a dry stream bed $[8,34,35]$. Two other water settlements, the Taos Pueblo Indian Water Rights Settlement and Agreement and the Zuni Indian Tribe Water Rights Settlement Act of 2003 and Agreement included significant provisions for cultural wetland restoration addressing groundwater and surface water use. For the Taos Pueblo Indian Water Rights Settlement, limits on groundwater withdrawals were set to limit impacts to tribal cultural and religious wetlands. For the Zuni Indian Tribe Water Rights Settlement, 5500 AFY of unappropriated flows were authorized to restore cultural and religious wetland Kolhu/wala:wa and Sacred Lake Hadin Kyaya with a 1984 priority date. Tribes have used other environmental protection legislations to advocate for the protection of their waters from overuse and contamination. These include the Clean Water Act, treaty rights, Endangered Species Act, as well as the ability of tribes to attain Water Quality Treatment as a State securing their authority to regulate water quality on their tribal lands.

\section{Examples of Tribal Water Resources Challenges}

A range of water resources challenges face tribes today. This section gives examples of water challenges facing tribes in the Southwestern United States. The first is the process of defining tribal water rights. The second is lack of access to water. The third is the effects of excessive use of water impacting water quantities on the reservation. The fourth is water contamination from mining, industrial, and agricultural activities. Finally, climate change and drought will amplify these existing water challenges.

The process of defining water rights can be locked in decades of litigation, adjudication, or negotiation due to the number of water users in the watershed and the legal complexities in court. If litigation is pursued, the tribe is typically the sole bearer of financial burden. In addition, the final rulings can have repercussions on other tribes in their water rights litigation. Even if a tribe wins the water right on paper, which is called a 'paper water right,' the tribe may not necessarily have the financial capital to extract and deliver their water [30]. This is the case in the Wind River Reservation where litigation resulted in water rights strictly for agricultural purposes and not for beneficial use, such as instream flows administered by the State Engineer [36]. Since the United States is trustee of federally recognized tribes, they are a party in tribal water rights cases, however, the U.S. may also potentially represent other competing interests such as that of federal agencies. Representing two parties in a case is normally a conflict of interest but current U.S. laws allows the U.S. to represent competing interests and thus are not held to the same standard as private fiduciary in tribal water rights cases. In sum, the U.S. Department of Justice may litigate on behalf of the tribe as an active partner or may play a passive role as a trustee for a federally recognized tribe.

Even if a water settlement is negotiated, it may receive opposition from the tribal community or grassroots because of discontent in the negotiated allocation such as in the Senate Bill 2109: Navajo-Hopi Little Colorado River Water Rights Settlement Act of 2012. In the final step, this settlement needed Congressional approval and Senator Jon Kyle (R-AZ, 1995-2012) introduced the settlement before Congress to garner support. In his opening remarks, Senator Kyle said, "Legally, the Navajo Nation and Hopi tribe may assert claims to larger quantities of water [than are outlined in the 
settlement] but they do not have the means to make use of those supplies in a safe and productive manner." This created uproar from the Navajo grassroots community because his statements implied the lack of the Navajo Nation's ability and resourcefulness to use the water. Yazzie identified this approach as a model of minimization of water rights not quantification [37]. In addition, grassroots communities were not involved in the negotiation at the community level as these negotiations were held behind closed doors. This widespread disapproval from both the Navajo and Hopi grassroots halted approval of the water settlement.

The second challenge is access to water. Approximately $9 \%$ of Native American homes in the United States lack safe and adequate water supplies and lack access to waste disposal facilities in comparison to $1 \%$ of U.S. homes [38]. Not only does this have implications for quality of health and life for tribal members, but it also dampens the economic growth on tribal lands subsequently impacting quality of life in terms of available jobs and infrastructure. In addition, some tribes may not be able to use groundwater sources due to lack of quality. For example on the Navajo Nation, in the southwestern portion of the reservation, groundwater is highly saline and can contain heavy metals, making it unsuitable for drinking or livestock purposes [39].

The third challenge is excessive water use and diversion impacting tribes. For the Pyramid Lake Paiute Tribe, excessive diversion at Derby Dam for agricultural use blocked access to upriver spawning grounds for fish and during a drought left dying fish for two miles downstream of the dam [35]. Since the Pyramid Lake Paiute Tribe is located at the terminal end of the river system, they are subject not only to excessive use but also by non-point pollution into the river by municipal, industrial, and agricultural practices. Another similar example is the Pueblo of Zia located 35 miles northwest of Albuquerque, NM near the confluence of the Jemez River and Rio Grande who are facing upstream impacts including recreational activity, agricultural diversion, and encroachment of the large cities of Rio Rancho and Albuquerque. The Pueblo of Zia encourages sustainability, self-sufficiency, and subsistence activities. Today, most of the tribal members hunt, gather, cultivate food crops, and raise livestock and Zia's economy is based on agriculture which is intertwined with their religion, government, social organizations, and livelihoods [40].

The fourth challenge is off-reservation and on-reservation contamination of water by mining, industrial, and agricultural uses. Regulating and minimizing impacts can be difficult when there are many non-tribal users who may be hard to identify until it is too late, such as in the case of abandoned mines. For the Laguna Pueblo, the abandoned Jackpile-Paguate Uranium Mine covers almost 8000 acres east of the village of Paguate and acid mine drainage leaks into the arroyos and streams flowing into the Rio Paguate and Rio Moquino, both of which are upstream of the village. In southern Arizona, thousands of gold and copper prospector abandoned mines exist that create both physical hazards and pools of acid mine drainage. Finally, hundreds of thousands of abandoned mines exist in Colorado upstream of the Mountain Ute, Southern Ute, and the Navajo Nation. Recently, on 5 August 2015, the Gold King Mine Spill, spilled three million gallons of acid mine drainage into the Animas and San Juan Rivers, which the tribes depend on [10,41].

Finally, short-term drought and climate change, which has impacts on natural systems affecting indigenous peoples everywhere, strains sometimes already stressed water infrastructure that may be lacking, inadequate, or poorly maintained. This increases the vulnerability of tribes to flooding, drought, and water-borne diseases [42]. Existing infrastructure can be damaged due to changes in water quality, water resources, and land subsidence [42]. A flood on the Fond du Lac Reservation in 2012 resulted in extensive crop loss of wild rice, which is a sacred food of great importance for many of the Midwestern tribes. On the Standing Rock Sioux Nation in North Dakota, silt and sludge closed a water supply intake pile when a 2003 drought caused water levels to drop to very low levels. In Alaska Native villages, beavers which can carry giardia are moving father and father north and are in northern rivers of Alaska which have not been occupied since the last ice age [43]. In light of these examples of the experience of diverse tribes, climate change and drought will likely amplify existing water challenges that face tribes in the Southwest today. 


\section{Collaborative and Participatory Approaches to Research and Resource Management}

\subsection{Tribal Sovereignty and Research Practices}

The principles embedded in federal Indian law and policy (discussed above) also govern the ways in which research is conducted by and with tribes. As outlined above, the federal government has a set of legal principles that govern its relationships with tribes and its responsibility to act in the best interest of tribes. The rights of inherent sovereignty retained by tribes dictate that researchers and other professionals seeking to work with tribes adhere to the standards set by tribal governments. As sovereign nations, tribes have the authority to control when, where, how, and whether research is conducted on their lands or among their citizens. Unfortunately, this right was not always recognized or respected. Prior to the resurgence of tribal sovereignty in the area of research, researchers often felt they had "the authority of the federal bureaucracy... behind them... [R]esearchers could set their own agenda and do as they pleased without having to consult with or defer to tribal polities. Research has always been deeply implicated in the colonial political context" [44]. This lack of oversight often led to abuse, misrepresentation, and exploitation of Native peoples by researchers [44-47].

Since the mid-1990s, a growing number of tribes have established their own research protocols and review boards $[44,47,48]$. While each tribe's regulations vary, some general principles are evident across the protocols. First, researchers must gain permission to conduct the research on tribal lands or with tribal members. This process may start with speaking with tribal elected officials who have the authority to approve research and/or applying to the tribal research office for a research permit. During the process of gaining permission, researchers should have open discussions with the approving body about data ownership, use, and sharing [46]. Some tribes consider all data collected on their lands to be their property and do not allow it to be shared with the general public (often a requirement of federal research grants). Researchers should be clear about the extent to which they can publish or share data from their proposed research and whether additional permissions or review might be required prior to publication. Some tribes may simply request that the original data be archived with them for use and access by tribal members.

In addition to any tribal government oversight, researchers must have any research involving people reviewed by their Institutional Review Board (IRB) to ensure that it complies with federal regulations regarding human subjects research (i.e., The Common Rule, 45 CFR 46) [49]. However, a critique of the standards set by The Common Rule governing human subjects research is that it focuses too much on individual rights and protections and does not explicitly cover the concerns of tribal communities regarding, for example, protection of local or traditional knowledge [46]. There are also questions of whether the research will benefit tribal members who invest their time in the research process. To strengthen IRB processes to increase protection for tribes, some institutions, such as The University of Arizona, review all research proposed in or with tribal communities to ensure compliance with tribal protocols $[44,48]$.

While these official review processes are fundamental to conducting ethical research with tribes, they are often just the first step in ensuring that tribal interests, needs, and knowledge are fully respected and braided into research and outcomes. It is important for researchers to take the time to learn the cultural context and sensitivities of the information being collected, such as how and when certain knowledge can be transmitted; the cultural significance of particular resources (see discussion above of water as a cultural resource), which imbues discussions with greater significance than the researcher may be aware of; and any prohibitions or proscriptions against discussing certain topics. It can sometimes be the case that certain communities within some tribal nations that are keepers of certain forms of knowledge may have their own expected protocols for researchers to respect that are stronger than those of their tribal governments. Given, as discussed earlier, that many tribal governments today do not correspond to the traditional governments, researchers should do the work to ensure they are paying respect to the overall research situation within a tribe, considering both the tribal government and the community $[16,50]$. Though in no circumstances should the complexity of 
tribes be used to play different governmental authorities and constituencies against one another or to serve as an excuse for avoiding formal tribal IRB processes or the formal involvement of tribal council. Lastly, researchers need to consider that certain members of tribes, especially elders or culture-bearers, are being constantly burdened with requests to work with researchers. These members often do not receive benefits from participation in research projects that are comparable to what the researchers gain in relation to their own careers and aspirations.

Scientists have a moral responsibility to respect indigenous knowledge systems as more than sources of data. Many indigenous peoples see themselves as sensitive to social, cultural, and political dimensions of knowledge systems that scientists have forgotten to pay attention to in relation to their own knowledge systems. Scientists may assume that it is normal to view plants, animals, elements (e.g., water) and ecosystems as mere resources with no cultural or spiritual value.

Yet many indigenous peoples see "water as a resource" as just one possible kind of relationship on which a knowledge system could be based. Many indigenous knowledge systems produce empirically valid claims using approaches to plants, animals, elements, and ecosystems as kin or clan relatives, who have agencies, spiritualities and personalities of their own [51-53]. Hypothetically, a researcher who treats water as a mere resource could accidentally insult or disrespect tribes or imply forms of handling or using water in research that are inappropriate. Thus, scientists should take pains to ensure that they do not privilege often unseen assumptions within their own knowledge systems that could lead them to sour their relationships with tribal collaborators.

External researchers and scientists are often not accustomed to or comfortable with the ways in which indigenous persons describe indigenous knowledge systems. For example, Native Americans often describe knowledge as knowledge in experience that is carried and embodied [52,53]. This is called 'lived knowledge' where knowledge cannot be separated from human experience and action. Burkhart gives an example of the Seneca people who planted corn, beans, and squash together because of traditional ceremonies and cultural stories about Three Sisters that told that planting these together would feed the people. This relationship is an illustration of the nitrogen cycle and nitrogen replenishment keeping the soil productive and fertile. Indigenous knowledge is based on patient observation and contemplation. Though just because indigenous persons describe their knowledge systems in this way, it should not be presupposed that this means that indigenous persons cannot understand and connect their knowledges to the approaches to knowledge assumed by others [54]. Understanding the differences between approaches to knowledge, even if just at the heuristic level, will arguably help researchers be better prepared to work with tribes and to have appropriate cultural sensitivities [54].

Tribal knowledge systems also involve different social institutions and relationships to politics than scientific knowledge systems do. As fields such as science studies and the philosophy of science have pointed out, any knowledge system works through social institutions, from political authorities to sources of support (e.g., funding), that set research priorities, assign powers and privileges to certain members or groups, create rituals and rites of passage, and so on. External researchers are often unaccustomed to seeing themselves as embedded within social institutions given their personal interest and passion in the pursuit of knowledge. Yet they are nonetheless embedded in social institutions that differ from those of tribal knowledge systems, creating the possibility for mismatch. For example, knowledge taken to be public by scientists may be tribal knowledge that should only be appropriately expressed in a certain ceremony. Another example is tribal knowledge about the location of a medicinal plant may not create political problems for scientists but it may for members of a particular tribe who could stand to lose access to harvesting those plants if their location is made public. Climate and Traditional Knowledges Workgroup (CTKW) calls this the "governance value" of knowledge, which scientists often times do not pay attention to with their own knowledge systems $[16,50,55]$. While tribal members often are open about the relationship of their knowledge systems with beliefs in the spirituality of nonhumans or the inherent ties between knowledge and social institutions and political agendas, scientists are often not comfortable with this. Scientists 
should approach collaborations with tribes initially more as diplomats than as fellow inquirers, given these differences.

Lomawaima summarizes the legal and political standards of research as well as the cultural and ethical requirements when working with tribes, into four "simple rules": (1) ask about the ethics of conducting research in each particular community; (2) do more listening than talking; (3) find and follow any and all tribal research rules or protocols; and (4) give something back to the community in exchange for their cooperation with your research [44]. Others have emphasized, in relation to these rules, that researchers do have to respect and follow tribal research protocols that emerge from cosmological frameworks for approaching the world that are very different from science $[51,52,55]$. Moreover, researchers should endeavor to consider their roles within larger U.S. settler colonial structures as professionals working for powerful universities, scientific organizations and agencies. Instead of understanding their research ethics as simply a matter of getting information from tribes without harming anybody; they can instead try to determine how their research will ultimately support the sovereignty, cultural revitalization, and well-being of tribal members, communities, and nations [55].

Given that this article addresses primarily external researchers who seek to work with tribes, we did not include decolonizing methodologies as part of the initial approaches, but seek to discuss it here given its overall importance for how external researchers approach tribes. Decolonizing methodologies, or indigenous research methodologies, emphasize an orientation to research that reconfigures how researchers relate to indigenous communities. For research to truly be beneficial, the research design itself has to emerge from indigenous conceptions, cosmologies, and frameworks for empirical inquiry. Decolonizing methodologies calls for indigenous peoples to develop their own research institutions for gaining and protecting knowledge that supports their sovereignty and the well-being of their community members [56]. While this literature focuses on the development of indigenous research, it has an important implication for researchers from universities and other institutions outside of tribes. External researchers, through their research, need to support the development of both tribal capacities to produce their own research, on tribes' own terms, and also ensure that their own research institutions are organized as best as possible to match up with tribal institutions, such as the development of indigenous research institutions within U.S. colleges, universities, and research institutions [55]. Indigenous research methodologies seeks to empower indigenous persons to take on the role of researcher in ways that respect the cultural protocols, use the assumptions of empirical validity, and advance political agendas of their communities and indigenous nations; they seek to pose direct, critical questions to non-indigenous researchers about what it would really mean to decolonize the relationship between powerful universities, scientific organizations, and agencies that often sponsor research with tribes.

\subsection{Collaborative Approaches to Natural Resource Management}

Not only is a more collaborative approach to research with tribes good ethical and legal practice, it can also be a more effective way to make natural resource management decisions, including those about water. Research on collaborative, or participatory, research processes involving scientists, stakeholders, and policy or decision makers has shown that participants tend to trust scientific information more [57] and are more likely to use it to inform decisions when they collaborated in the process of developing the knowledge [58,59]. However, we know from research like Beierle [60], Nadasdy [61], Rowe and Frewer [62], Stern and Fireberg [63], and Ford et al. [64], among others, that not all collaborative processes are equal. The ways in which scientists engage with other parties-the processes they use-matters to the outcomes. We identified five approaches to engaging tribes on water and other natural resource management issues, including (1) Tribal Participatory Research (TPR); (2) Boundary Work; (3) Adaptive Water Governance; (4) Community Based Adaptation (CBA); and (5) Indigenous Ecological Knowledge (IEK) Engagement Structures (Table 1). Most of the approaches meet Lomawaima's [43] four simple rules of tribal research to various degrees. 
Particular attention should be paid to the process of collaborating on resource management research and policy decisions with and among indigenous communities. Fisher and Ball propose an approach they call tribal participatory research (TPR), which is based on participatory action research (PAR), which emphasizes inclusion of community members throughout the research process [65]. TPR is a synthesized model created to address the historical legacy of exploitation of indigenous communities by outside researchers. They note that PAR was created based on the principle of using research to have a liberating effect and increase self-determination [66], key components that have been missing from much research involving indigenous communities in the past. TPR acknowledges the need to incorporate community-specific cultural factors, acknowledgement of historical trauma, involvement of community, and protection of tribal interests. The TPR mechanisms focus on tribal oversight, the use of a facilitator, training and employing of community members as project staff, and the use of culturally specific assessment and intervention methods. Tribal oversight includes a tribal resolution, tribal advisory committee, and tribal research protocols. Although TPR was developed for social sciences, the mechanisms outlined by TPR is significant for engaging tribes on water resources topics.

Boundary work seeks to negotiate boundaries between science and other knowledge forms in order to both make sense of different knowledges and generate new knowledge. Boundary work focuses on creating politically- and culturally-sensitive processes even when the goals of collaboration are explicitly about knowledge exchange. Robinson and Wallington examined the integration of indigenous knowledge into co-management systems in Australia and found that managers needed to take into account the institutional landscapes as well as current socio-ecological landscapes, because older management or legal structures can inhibit the development of new co-management structures. Boundaries can also create barriers to collaboration [67]. Robinson and Wallington [67] identified three factors in effective boundary work: meaningful participation in setting goals and co-producing knowledge; governance to ensure that boundary work is accountable; and co-production of boundary objects (e.g., maps, or interpretive frameworks that all participants agree to as trustworthy and respectful of their differences).

Adaptive water governance requires governance to adapt to uncertainty and change through ongoing learning, institutional integration, collaboration, and co-management partnerships [68]. It is structured as polycentricinstitutional arrangements that nest decision-making and integration of roles and activities between state and non-state entities and is useful where significant knowledge gaps exist. Adaptive water governance manages uncertainty through water entitlements that solidify indigenous claims and basin planning that incorporates indigenous knowledge. Water can be re-allocated in response to changing conditions and values and basin planning regularly reviews and updates targets. Water entitlements acknowledge indigenous claims and provide infrastructure and institutional capacity. Water planning goals, structures, and processes are based on indigenous knowledge and perspectives. Bark et al. [68] found that indigenous communities with existing land holdings were better positioned to influence water management and policy than those who lacked holdings.

Community based adaptation (CBA) is a community-led process, based on communities' priorities, needs, knowledge, and capacity to empower people to plan for and cope with the impacts of climate change. Ford et al. unpack some of the challenges and potential issues with even the most well-intentioned participatory research work focusing on CBA [64]. Based on their experiences with CBA approach to climate change impacts, they note that researchers cannot assume that research has a positive role to play in a community, just because it uses participatory processes; sometimes-new research is not the answer to a community's needs. Further, they stress the need to manage expectations - those of the community and those of the researchers-and be realistic about what research can actually achieve in a community. Finally, they caution researchers interested in the CBA approach to invest time in planning and coordinating their work well in advance, because to be truly effective a participatory approach requires significant time, effort, and resources. 
Hill et al. analyzed 21 case studies of environmental management decisions in Australia that included indigenous communities to develop a typology of engagement types based on how they integrate indigenous environmental traditional knowledge (TK) with Western science, how TK is managed throughout the process, and how TK is integrated into management strategies [69]. They identify four general types of engagement: Indigenous Governed collaborations (IG); indigenous-driven Co-Governance (ICoG); Agency-driven Co-Governance (ACoG), and agency governance (AG). Indigenous-governed collaborations (IG) and indigenous-driven co-governance (ICoG) provide better prospects for integration of TK because indigenous peoples retain control over that knowledge. IGs stem from indigenous initiatives such as a confederation of indigenous nations who are focused on environmental issues, actions, and policies. IGs focus on advancing distinct indigenous society and cultures with inclusive participation of indigenous people with indigenous people retaining significant power. On the other hand, ICoG are created in response to government initiatives but empower indigenous interests and authority while recognizing the need to improve indigenous and non-indigenous people's capacity to operate and with significant power sharing with non-indigenous interests.

Cronin and Ostergren analyzed three tribal collaborative water management structures including two tribes in the Northwest and one tribe in the Southwest [70]. In this comparative study involving the analysis of 31 tribal and non-tribal interviews, Cronin and Ostergren [70] identified six factors that influence tribal engagement in water management discussions: (1) tribal cultural connection to aquatic resources; (2) political clout and legal standing of tribes; (3) relationships between tribal and non-tribal communities and relevant agencies; (4) recognition of the benefits of collaboration; (5) consistency and vision of tribal leaderships; and (6) the availability of resources to tribes. Cronin and Ostergren [70] stated that the presence or absence of any factor may not determine tribal engagement. Their recommendation of persistently seeking tribal input aligned with Lomawaima's [43] second rule, however, asking about ethics, tribal protocols, and giving back is not emphasized, instead they emphasize that tribal and non-tribal partners should seek to work together, share stories, and find whatever possible common ground there is. Notably, Cronin and Ostergren [70] suggest that non-tribal partners engage tribes early on such as in the planning phase and plan to make a long-term commitment.

Table 1. Selected five approaches of engaging tribal members, communities, and nations in water management discussions.

\begin{tabular}{ccccc}
\hline $\begin{array}{c}\text { Tribal } \\
\text { Participatory } \\
\text { Research [65] }\end{array}$ & $\begin{array}{c}\text { Boundary Work } \\
\text { [67] }\end{array}$ & $\begin{array}{c}\text { Adaptive Water } \\
\text { Governance [68] }\end{array}$ & $\begin{array}{c}\text { Community Based } \\
\text { Adaptation (CBA) [64] }\end{array}$ & $\begin{array}{c}\text { Indigenous Ecological } \\
\text { Knowledge Engagement } \\
\text { Structures ([69]) }\end{array}$ \\
\hline $\begin{array}{c}\text { Application of } \\
\text { participatory action } \\
\text { research to a new } \\
\text { context for tribal } \\
\text { communities }\end{array}$ & $\begin{array}{c}\text { Using scientific and } \\
\text { indigenous } \\
\text { knowledge to } \\
\text { co-manage } \\
\text { resources }\end{array}$ & $\begin{array}{c}\text { A hybid planning } \\
\text { model that } \\
\text { combines scientific, } \\
\text { institutional, and } \\
\text { social processes }\end{array}$ & $\begin{array}{c}\text { Commity-led process } \\
\text { based on communities' } \\
\text { priorities, needs, } \\
\text { knowledge, and capacities, } \\
\text { which should empower } \\
\text { people to plan for and } \\
\text { cope with challenges }\end{array}$ & $\begin{array}{c}\text { Indigenous Governed } \\
\text { collaborations (IG), } \\
\text { Indigenous-driven } \\
\text { Co-Governance (ICoG), } \\
\text { Agency-driven }\end{array}$ \\
$\begin{array}{c}\text { Co-Governance (ACoG), and } \\
\text { Agency Governance (AG) }\end{array}$ \\
\hline
\end{tabular}

\subsection{Braiding Traditional Knowledge with Water Management}

When new water management structures are designed, they should explicitly allow local people to use and refine their own knowledge system in ways that maintain the integrity of the knowledge practices, according to Hill et al. [69]. This kind of flexibility requires a different type of approach to engagement and integration of new knowledge; it requires the kind of collegial engagement between scientists, decision-makers, and other participants, which, as described by Biggs [71] and consistent with Smith [56] and Whyte [55], scientists actively support the production of local or indigenous knowledge systems, not just the integration of local knowledge into Western science frameworks. 
The challenge of how to braid Western and indigenous sciences in ways that are beneficial to both knowledge systems has been addressed in several places by Huntington $[18,72,73]$. Huntington urges Western scientists to carefully consider how they use the term traditional knowledge, to define it clearly and carefully to avoid misrepresenting the knowledge, and to recognize that there may be distinctions in types of knowledge within the community. Robinson and Wallington [67] raise a similar point and note the importance of establishing a relationship with the community that will facilitate the outsiders' understanding and use of traditional knowledge. Latiluppe claims that for "TK to advance the priorities and goals of Indigenous research partners and to be of benefit to Indigenous peoples, it is paramount that researchers consider their positionality and anticipate the outcomes of particular approaches within situated contexts" [74]. Whyte claims that "environmental scientists and policy professionals, indigenous and non-indigenous, should not be in the business of creating definitions of TK. Instead, they should focus more on creating long term processes that allow the different implications of approaches to knowledge in relation to stewardship goals to be responsibly thought through" [53].

A group of indigenous scholars with significant experience working on climate change and other resource management and planning issues have developed a set of guidelines for the use and integration of traditional knowledge into management planning efforts [16]. The purpose of these guidelines is to increase understanding for the protection and role of traditional knowledge in climate initiatives for federal and intergovernmental agencies. The eight guidelines outline principles of engagement and protocols for engaging tribes when it relates to traditional knowledge and understanding the risks tribes face when they decide to engage. As was mentioned earlier, the principles of engagement are to "cause no harm" and "free, prior and informed consent" indicating that there is fairness, early engagement, transparency, and the right to engage or disengage at any time. The eight guidelines are (1) understand traditional knowledge; (2) know that tribes have a right not to participate; (3) communicate risks to tribes and help tribes to understand risks; (4) establish an institutional interface; (5) train federal agency on traditional knowledge, its protection, and related policies and protocols; (6) establish specific directions to uphold TK protections; (7) recognize multiple knowledge systems; and (8) develop guidelines for review of grant proposals. Although these guidelines are focused on traditional knowledge in climate initiatives, the principles outlined are very applicable to environmental research more broadly.

\section{Case Studies}

Five case studies involving engaging Southwestern tribes on water management and water topics will be discussed. The manner in which tribes were engaged, the effectiveness of engagement, and the desires and concerns resulting from the engagement of the tribe will be discussed. The five cases studies are the Hopi Drought Study, the Pyramid Lake Paiute Tribe (PLPT) climate change project, the Water Resources Research Center (WRCC) Annual Conference focusing on "Indigenous Perspectives on the Sustainable use of Water", the WRCC's engagement of tribes to create a roadmap for considering environmental water demands, and the Colorado River Basin Tribal study and the effort to engage tribes. The first four are cases led by University of Arizona researchers. The varying levels of approval by the tribe and university research institutions are summarized in Table 2.

Table 2. Tribal and research approvals received by case study.

\begin{tabular}{|c|c|c|c|c|c|}
\hline Case & Purpose & $\begin{array}{l}\text { Tribal } \\
\text { Council }\end{array}$ & $\begin{array}{l}\text { Tribal } \\
\text { IRB }\end{array}$ & $\begin{array}{l}\text { University } \\
\text { IRB }\end{array}$ & $\begin{array}{l}\text { Community/Grassroots } \\
\text { Support/Resolutions }\end{array}$ \\
\hline (1) Hopi Drought Study & Drought planning & $\boldsymbol{v}$ & $v$ & $v$ & $v$ \\
\hline & $\begin{array}{l}\text { Climate change and } \\
\text { water planning }\end{array}$ & $v$ & $v$ & $v$ & $\checkmark$ \\
\hline $\begin{array}{l}\text { (3) Indigenous Water } \\
\text { Conference }\end{array}$ & Water management & & & & $\checkmark$ \\
\hline $\begin{array}{l}\text { (4) Environmental } \\
\text { Demands Roadmap }\end{array}$ & $\begin{array}{l}\text { Water management } \\
\text { planning \& policy }\end{array}$ & & & $v$ & \\
\hline $\begin{array}{l}\text { (5) Colorado River } \\
\text { Basin Tribal Study }\end{array}$ & $\begin{array}{l}\text { Water management } \\
\text { planning \& policy }\end{array}$ & $\checkmark$ & & & \\
\hline
\end{tabular}




\subsection{Hopi Tribe Drought Study}

The Hopi Department of Natural Resources (HDNR) has been collaborating with researchers from the University of Arizona (UA) to develop a drought monitoring framework to help HDNR address the drought impacts on farming, ranching, and cultural traditions occurring for at least 15 years. The framework was developed using a collaborative research project that included rapid assessment, organizational ethnography, and participant observation, as well as interviews and multiple discussions with Hopi citizens and employees for approximately 5 years. The goal of the project was to ensure that Hopi concerns were at the forefront regarding drought, existing monitoring and knowledge practices, and capacity to respond to drought impacts. By relying on local knowledge and skills, the drought monitoring framework was designed to harness local data in ways that support local decisions, rather than relying entirely on instrumental data from external sources, which is sparse across Hopi lands. For example, the team noted that the current drought plan relied on data not readily accessible to HDNR staff, making it difficult to declare (or to undeclare) drought. However, HDNR staff were already collecting environmental status information through several programs, including water resources and range management that shed ample light on drought conditions in the region. The shift to locally controlled data, the team hopes, will place more control in the hands of local decision makers and community members who are most affected by drought impacts [75].

\subsection{Pyramid Lake Paiute Tribe Climate Change Project}

Researchers from The University of Arizona, University of Nevada Las Vegas, and the U.S. Geological Survey have been collaborating with the Pyramid Lake Paiute Tribe in Nevada to identify water-specific vulnerabilities to climate change $[35,76]$. When interviewed about their experiences working together (by one of the authors, Meadow), both the researchers and the PLPT staff discussed important practices when researchers collaborate with tribes, particularly on sensitive issues involving water and water rights. For example, although PLPT does not have its own research review board, the lead investigator (author Chief) ensured that she had the support and consent of the tribal council by formally requesting their cooperation in the project and received a letter of support from the (then) tribal chairperson that documented permission to undertake the research and the tribe's commitment to collaboration. Throughout the project, the research team checked with PLPT staff to ensure that they were following community protocols regarding meetings, interviews, or other forms of data-gathering. The researchers presented before the PLPT tribal council on an annual basis, to receive approval in research changes, and to present final reports. They worked with PLPT staff to organize community workshops to ensure that local protocols were followed. A high degree of trust developed between the researchers and PLPT staff, which was demonstrated when the potentially sensitive issue of protected cultural knowledge came up in the course of the research. Rather than become a hurdle, both groups were able to discuss what to do with cultural knowledge, should it arise in interviews or other discussions, and come to an understanding both were comfortable with.

\subsection{Indigenous Perspectives on Sustainable Water Practices Conference}

The University of Arizona Water Resources Research Center (WRCC) hosts an annual conference on various water management topics each year. Due to the recent highly contentious proposed Little Colorado Water Settlement, a significant number of Navajo and Hopi grassroots members advocated to have a voice at the 2014 conference on "Closing the Gap between Water Supply and Demand." To highlight the voice of the indigenous communities, the 2015 WRCC conference was focused on "Indigenous Perspective on Sustainable Water Practices" [77]. A tribal advisory committee (TAC) was formed to represent the indigenous perspectives across Arizona and provide guidance and advice on the conference agenda and speakers. TAC met monthly to plan steps. In this planning process, a survey was developed and distributed across tribes to determine conference title, topics, speakers, and provide input for the indigenous water conference. The Gila River Indian Community (GRIC) 
hosted the conference and over 300 individuals from 49 municipalities and 13 Native communities throughout Arizona attended the conference which was a record number of attendees for WRCC annual conferences. The GRIC Governor Stephen Lewis provided welcome remarks highlighting the celebration of the 10th Anniversary of the Gila River Water Settlement and a challenge for tribal water security into the future and an investing in the youth. John Echohawk (Pawnee), founder of the Native American Rights Fund, provided the opening remarks encouraging an active dialogue between grassroots tribal members and tribal leaders as well as non-tribal environmental managers. The conference was a convergence of traditional grassroots perspectives and environmental managers resulting in mutual learning and respect. Arizona State Senator Carlyle Begay (Diné) noted that the event represented " ... a very much needed conference, generating a lot of great discussion, a lot of great insight, and most importantly great ideas in moving our communities forward in discussions about the future of our water resources".

\subsection{Arizona's Roadmap for Considering Water for Arizona's Natural Areas}

The University of Arizona Water Resources Research Center (WRCC) created a roadmap that outlines considerations for water for Arizona's natural areas in Arizona water management and planning decisions [78]. Often times the water demands needed for the environment, such riparian water demands and aquatic ecosystems, are not considered in state management plans. The objective was to promote a discussion on ways that stakeholders can address environmental water demands under the constraints of limited water supplies and existing water rights. The WRCC engaged a diverse set of participants including academic, business, environmental farming, mining, municipal power, ranching, and tribal perspectives through surveys, focus groups, workshops, and presentations.

Considering that tribes have a deep connection to the natural environment where water for the environment is respected, this topic was expected to be of great interest for tribal communities and nations. Among the various participants, 40 tribal persons were engaged, which was about average compared to the other non-tribal participants. The tribal participants were recruited as voluntary participants. With 22 tribes in the state of Arizona and a land base of nearly a third of the state, the recruitment of tribal participants was on an individual basis through tribal organizations, consortiums, and meetings where tribal environmental managers typically attended. Grassroots tribal environmentalists tended to be active participants seeking to be involved in this discussion. There was no report back to specifically to tribes on the results of the study, however, the results, have positive implications supporting the deep connection of tribes to the natural environment.

\subsection{Colorado River Basin Watershed Tribal Study}

The 2012 Colorado River Water Supply and Demand Study was a \$5.5 million three-year study by the Bureau of Reclamation and the Colorado Basin States to develop a comprehensive plan to address risks posed by imbalances between Colorado River water supply and water needs in the basin [79]. Tribes voiced the desire for the Study to engage tribes individually on a tribe-by-tribe basis. On 18 September 2013, the Department of Interior and the BOR entered into a collaborative agreement to focus on tribal concerns and needs by working with the Ten Tribes Partnership including the Chemehuevi Indian Tribe, Cocopah Indian Community, Colorado River Indian Tribes, Fort Mojave Indian Tribe, Jicarilla Apache Nation, Navajo Nation, Quechan Indian Tribe, Southern Ute Indian Tribe, Ute Mountain Ute Indian Tribe, and Ute Tribe of the Uintah and Ouray Reservation. The Ten Tribes Partnership will focus the study on tribal water rights. BOR expects to release this report in December 2016.

\section{Discussion}

In considering the engagement of the five cases, we built upon the four "simple rules" of tribal research which are to ask about ethics, do more listening, follow tribal research protocols, and give back to the community. Specific engagement components were identified under each of the four simple 
rules. Asking about ethics means having cultural sensitivity to understand cultural protocols and to rethink one's role as a researcher in relation to the institutional context that tribes operate in that may produce risks that are not typical for researchers to consider. Doing more listening includes listening to the tribal leaders and community members to understand what their research needs are, if research is needed and useful, and allowing the community to develop and drive research goals. Following tribal protocols includes having approval by the tribe to conduct research or having tribal oversight such as a tribal advisory board to guide the project goals. Giving back means having on-going and regular communication with the tribe to update them on efforts. Giving back also means that the tribe owns the data and knowledge and data co-produced or acquired through the project should be transferred back to the tribe. Finally, giving back means reporting back to the tribe on project results (Table 3). From the literature and examining the five case studies, successful engagement with tribes involved engagement of tribal leaders and members at different levels, tribal oversight, on-going dialogue, transparency of data, and reporting back.

Table 3. Components to gain trust and build partnerships with tribes by case study [44].

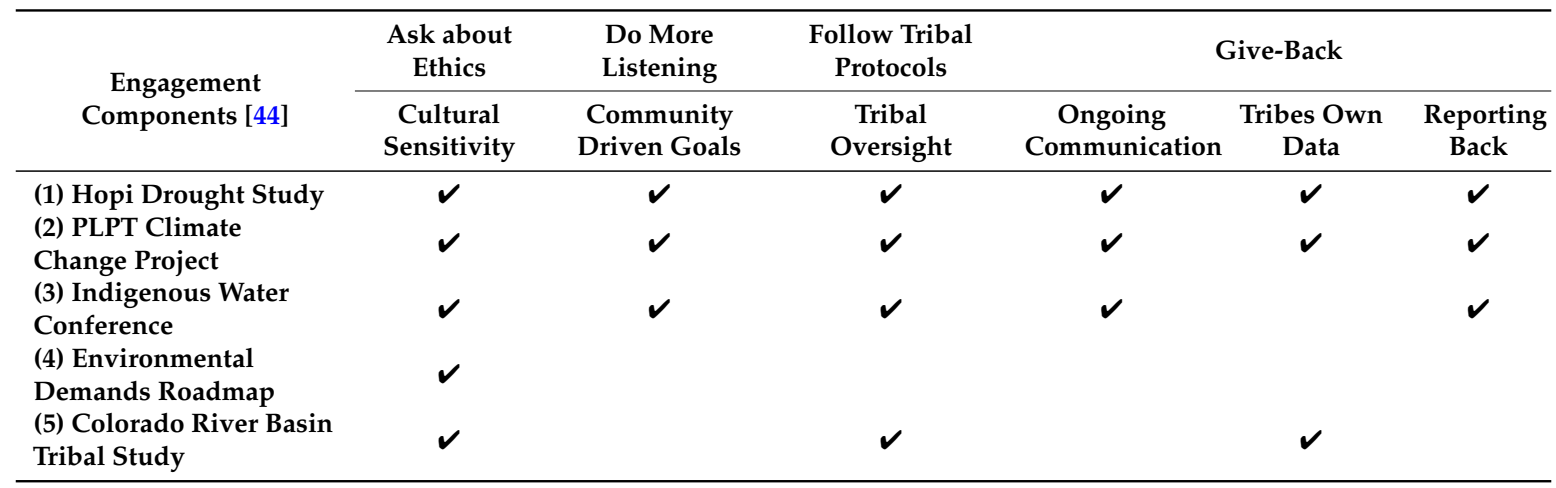

All of the cases represent the use of different elements for collaborative research. Both the Hopi drought project and the Pyramid Lake Paiute Project collaborative water management projects are university led projects that engage tribal partners in the research objectives. Both projects required the university human subjects research review approvals and tribal research approvals (Table 2). The Hopi drought project explicitly included tribal resource managers in data collection and analysis. These projects, as many of the others, sought ways to make the work relevant to improving tribes' capacities as sovereigns. Moreover, in many of the cases, researchers were both respectful to tribal governments and also paid attention to the dynamics of communities within tribes that are not associated with the government, such as the grassroots communities.

The Pyramid Lake Paiute Project engaged with a broad spectrum of tribal members and employees. The tribal chairperson, who has a background in water resources management, invited and supported the project. The chairperson participated in the climate change perception survey, individual interviews, and focus groups. The project team produced written and oral annual reports to the tribal council who guided and approved research activities. The natural resources oversight committee reviewed and approved public abstracts, presentations, and manuscript publications. The tribal environmental managers were engaged in focus groups and water management planning workshops on a regular basis. A tribal liaison from the tribal environmental was assigned to the project to receive weekly updates, participate in project meetings, and assist in coordinating meetings, workshops, and presentations with the tribe. In addition to focus groups held with the environmental managers, surveys at household levels were administered by a tribal college student, and a community workshop on water management was conducted. Finally, the project involved Native American researchers including faculty and students. This project was successful in engaging the tribe because of the involvement of tribal leadership and process of receiving tribal government research approvals through a tribal protocol. In addition, consistent communication through written, verbal (in person and via teleconference), 
social media, website, and newspaper articles contributed to on-going engagement. At a time when there were few tribes engaged in climate change research, PLPT became a leader in tribal climate research. Outputs from this project were fruitful including a publication in the journal of Climatic Change, several community videos, and two streams of funding.

The HDNR collaboration also started with an invitation to the researchers from the (now retired) director of the Department of Natural Resources to provide guidance on developing a more robust drought-monitoring plan than was in place at the time. The researchers and local resource managers collectively defined and redefined the research scope to address local concerns and decision frameworks [75]. University researchers (all who were not Native American) conducted early interviews, focus groups, and participant observations involving resource management staff. A Hopi researcher, employed by the university, conducted interviews with community members, that at times touched on traditional knowledge and practices [75].

The indigenous conference on sustainable water management was successful in engaging tribes because it provided a venue in which to discuss indigenous perspectives at a statewide conference. The conference's goals were to inform non-tribal attendees of indigenous perspectives and to engage tribal attendees. A tribal advisory committee oversaw the organizing of the conference. The advisory committed administered a post-conference survey to collect feedback on the content and structure of the conference. The conference had a record number of attendees in comparison to past versions of the conference that did not explicitly address tribal water issues.

The environmental demands project resulted in a modest number of tribal members who were engaged in discussing water management policies that would consider water for the environment. The project received university IRB approval. With a state-wide scope of engaging diverse participants, there was no requirement for a specific tribal IRB approval. A request for tribal involvement was presented at an intertribal consortium supported by the tribal water working group coordinator, however, the request was met by skepticism and hesitancy because the word "research" was mentioned in the introduction of the Water Resources "Research" Center. There was no involvement of the tribal water working group or tribes represented at the intertribal consortium. Recruitment of tribal members was broad and two Native American representatives served on the advisory steering committee. A few tribal members attended each of the many workshops and focus groups. Reporting was conducted as a whole to the entire group of participants, however, there was no specific reporting conducted for specific tribes and tribal community groups. Nonetheless, tribal grassroots members were actively involved and willing to provide feedback and contributed to understanding the grassroots perspectives on environmental demands from a tribal perspective.

The Colorado River Basin Study engaged tribes that were directly given responsibilities to provide input for tribal water rights in the Colorado River Basin. The Colorado River Basin Study did not engage tribes at the community level where the most active and vocal citizens often are found. It is unclear what types of publications directed towards the tribal citizen were created to communicate results in layman terms. Use of tribal linguists and facilitators to engage and inform tribal members at the community level would prove to be useful and productive.

\section{Conclusions}

Because of the deep connection tribes have to the natural environment and tribal specific challenges in water management, the manner of engaging tribal participants, from individuals to communities to nations, is important to the success of the project, goals, and dialogue. This paper synthesized approaches to engaging tribal participants from small-scale community level engagement to basin level multi-tribal engagement for various goals of tribal water management, state water management dialogue, receiving input on state water policy for the environment, and basin wide water policy development. The type of engagement is goal- and tribe- specific and there are many levels of engagement and approvals and support needed. Successful engagement with tribes involves comprehensive engagement of diverse tribal audiences, tribal oversight, on-going dialogue 
transparency of data, and reporting back. As climate change, along with existing issues surrounding drought, mining, and uncertain water rights, stresses tribal water resources in the southwestern U.S., engaging tribes in water management discussions becomes more critical. This paper has provided an overview of many of the social, cultural, political, and historical considerations that are key to successful collaborations between researchers, resource managers, policy makers, and tribes.

Acknowledgments: The authors would like to acknowledge the funding sources of four of the case studies. The Hopi Drought Study acknowledges support by the National Oceanic and Atmospheric Administration (NOAA) Climate Program Office Sectoral Applications Research Program (SARP) Grant (\#NA10OAR4310183) and the views expressed in this publication represent those of the authors and do not necessarily reflect the views or policies of NOAA. The Pyramid Lake Paiute Tribe climate change project acknowledges support by the National Science Foundation (NSF) Nevada Experimental Program to Stimulate Competitive Research (EPSCoR) seed grant (\#EPS0814372) and the United States Geological Survey Grant/Cooperative Agreement (\#G12AC20506). The contents of this publication are solely the responsibility of the authors and do not necessarily represent the official views of the USGS. The Water Resources Research Center (WRCC) Indigenous Perspectives on the Sustainable Water Practices Conference acknowledges support from the Gila River Indian Community. The WRCC Arizona's Roadmap for Considering Water for Arizona's Natural Areas acknowledges support from from the Nina Mason Pulliam Charitable Trust.

Author Contributions: Karletta Chief conceived and led the writing of the article. All authors contributed to writing the outline and manuscript.

Conflicts of Interest: The authors declare no conflict of interest.

\section{Abbreviations}

The following abbreviations are used in this manuscript:

$\begin{array}{ll}\text { ACoG } & \text { Agency-driven Co-Governance } \\ \text { AG } & \text { Agency Governance } \\ \text { BIA } & \text { Bureau of Indian Affairs } \\ \text { CBA } & \text { Community Based Adaptation } \\ \text { CTKW } & \text { Climate and Traditional Knowledges Workgroup } \\ \text { GRIC } & \text { The Gila River Indian Community } \\ \text { HDNR } & \text { Hopi Department of Natural Resources } \\ \text { IEK } & \text { Indigenous Ecological Knowledge } \\ \text { ICoG } & \text { Indigenous-driven Co-Governance } \\ \text { IG } & \text { Indigenous Governed collaborations } \\ \text { IRB } & \text { Institutional Review Board } \\ \text { PAR } & \text { Participatory Action Research } \\ \text { PIA } & \text { Practicable Irrigable Acreage } \\ \text { PLPT } & \text { Pyramid Lake Paiute Tribe } \\ \text { TAC } & \text { Tribal Advisory Committee } \\ \text { TK } & \text { Traditional Knowledge(s) } \\ \text { TPR } & \text { Tribal Participatory Research } \\ \text { UA } & \text { University of Arizona } \\ \text { WRCC } & \text { Water Resources Research Center }\end{array}$

\section{References}

1. Whyte, K.P. Indigenous women, climate change impacts and collective action. Hypatia J. Fem. Philos. 2014, 29, 599-616. [CrossRef]

2. McGregor, D. Honouring our relations: An Anishnaabe perspective on environmental justice. In Speaking for Ourselves: Environmental Justice in Canada; Agyeman, J., Cole, P., Haluza-Delay, R., Eds.; University of British Columbia Press: Vancouver, BC, Canada, 2009; pp. 27-41.

3. Black, M.S. Indian entities recognized and eligible to receive services from the Bureau of Indian Affairs. Fed. Regist. 2012, 44, 47868-47873.

4. Norris, T.; Vines, P.L.; Hoeffel, E.M. The American Indian and Native Population: 2010. 2010 Census Briefs. 2012. Available online: http:/ / www.census.gov/prod/cen2010/briefs/c2010br-10.pdf (accessed on 4 July 2016).

5. Wilkinson, C. Crossing the Next Meridian: Land, Water, and the Future of the West; Island Press: Washington, DC, USA, 1992.

6. Tarlock, A.D. Prior appropriation: Rule, principle, or rhetoric. NDL Rev. 2001, 76, 881-910. 
7. Winters v. United States. 207 U.S. 564 (1908). Available online: https://supreme.justia.com/cases/federal/ us/207/564/ (accessed on 16 August 2016).

8. Rancier, R. Assessing Tribal Water Rights Settlements as a Means for Resolving Instream Flow Claims: A Comparative Case Approach. Master's Thesis, Oregon State University, Corvallis, OR, USA, 2012.

9. Dustan, A. With anything manmade there is going to be danger: The cultural context of Navajo opinions regarding snowmaking on the San Francisco Peaks. Indig. Policy J. 2010, 21, 2.

10. Beamer, P.; Chief, K.; Borrero, N.; Rivera, B. Water is Our Life: How a Mining Disaster Affected the Navajo Nation. Truthout News. 2016. Available online: http://www.truth-out.org/news/item/36049-water-is-ourlife-how-a-mining-disaster-affected-the-navajo-nation (accessed on 4 July 2016).

11. McGregor, D. Traditional knowledge: Considerations for protecting water in Ontario. Int. Indig. Policy J. 2012, 3, 11 .

12. Arquette, M.; Cole, M.; Cook, K.; LaFrance, B.; Peters, M.; Ransom, J.; Sargent, E.; Smoke, V.; Stairs, A. Holistic risk-based environmental decision-making: A Native perspective. Environ. Health Perspect. 2002, 110, 259-264. [CrossRef] [PubMed]

13. Foushee, L.; Gurneau, R. (Eds.) Sacred Water: Water for Life; North American Water Office: Lake Elmo, MN, USA, 2010.

14. McGregor, D. Linking traditional ecological knowledge and western science: Aboriginal perspectives. In Proceedings of the 2000 State of the Lakes Ecosystem Conference. Can. J. Nativ. Stud. 2008, 28, 139-158.

15. Hand, J.P. Co-operating to protect the shining big sea water and its siblings: Consultation with Native Peoples in protecting the Great Lakes. In Tribes, Land, and the Environment; Krakoff, S.A., Rosser, E., Eds.; Ashgate Publishing Company: Burlington, VT, USA, 2012; pp. 151-170.

16. Climate and Traditional Knowledges Workgroup (CTKW). Guidelines for Considering Traditional Knowledges in Climate Change Initiatives. Available online: http:/ / climatetkw.wordpress.com (accessed on 4 July 2016).

17. Redsteer, M.H.; Kelley, K.B.; Francis, H.; Block, D. Increasing vulnerability of the Navajo people to drought and climate change in the southwestern United States: Accounts from tribal elders. In Special Report on Indigenous People, Marginalized Populations and Climate Change; Nakashima, D., Rubis, J., Krupnik, I., Eds.; Cambridge University Press: New York, NY, USA, 2014.

18. Huntington, H.P. Using traditional ecological knowledge in science: Methods and applications. Ecol. Appl. 2000, 10, 1270-1274. [CrossRef]

19. Cherokee Nation v. Georgia. 30 U.S. 1. Available online: https://www.law.cornell.edu/supremecourt/text/ 30/1 (accessed on 15 August 2016).

20. United States Court of Appeals for the Federal Circuit. Available online: https://www.narf.org/nill/ bulletins/cta/documents/navajo.pdf (accessed on 15 August 2016).

21. United States v. Mitchell, 445 U.S. 535 (1980). Available online: https://supreme.justia.com/cases/federal/ us/445/535/case.html (accessed on 15 August 2016).

22. Mitchell v. United States, 664 F.2d 265 Ct.Cl. 1981. Available online: https://casetext.com/case/mitchell-vunited-states-21 (accessed on 15 August 2016).

23. In the United States District Court for the District of Columbia. Available online: http://www.indiantrust. com/docs/IIM_Joint_Motion_for_Approval.pdf (accessed on 15 August 2016).

24. Indian Reorganization Act. Available online: http://heinonline.org/HOL/LandingPage?handle=hein. amindian/indireac0003\&div=1 (accessed on 15 August 2016).

25. General Allotment Act, Act of 8 February 1887 (24 Stat. 388, ch. 119, 25 USCA 331). Available online: https://www.iltf.org/resources/land-tenure-history/historical-allotment-legislation/generalallotment-act (accessed on 15 August 2016).

26. Singletary, L.; Emm, S.; Hill, G. An assessment of agriculture and natural resource extension program needs on American Indian reservations in Idaho, Nevada, Oregon, and Washington. Available online: http:/ /www.joe.org/joe/2011april/a2.php (accessed on 8 August 2016).

27. Shoemaker, J.A. Like snow in the spring time: Allotment, fractionation, and the Indian land tenure problem. Wis. Law Rev. 2003, 2003, 10-61.

28. Arizona v. California. 373 U.S. 546 (1963). Available online: https://supreme.justia.com/cases/federal/us / 373/546/ (accessed on 15 August 2016). 
29. 43 U.S. Code $§ 666$. Suits for Adjudication of Water Rights. Available online: https://www.law.cornell.edu/ uscode/text/43/666 (accessed on 15 August 2016).

30. Colby, B.G.; Thorson, J.E.; Britton, S. Negotiating Tribal Water Rights Fulfilling Promises in the Arid West; University of Arizona Press: Tucson, AZ, USA, 2005; p. 190.

31. Arizona v. California, 460 U.S. 605 (1863). Available online: https://supreme.justia.com/cases/federal/us/ 460/605/case.html (accessed on 15 August 2016).

32. Franks, M.C. The uses of the practicably irrigabe acreage standard in the quantification of reserved water rights. Nat. Resour. J. 1991, 31, 449-585.

33. Cosens, B. The measure of Indian water rights: The Arizona homeland standard, Gila River Adjudication. Nat. Resour. J. 2002, 42, 835-872.

34. D'Estrée, T.P.; Colby, B.G. Braving the Currents: Evaluating Environmental Conflict Resolution in the River Basins of the American West; Kluwer Academic Publishers: Boston, MA, USA, 2004.

35. Gautam, M.; Chief, K.; Smith, W.J., Jr. Climate change in arid lands and Native American socioeconomic vulnerability: The case of the Pyramid Lake Paiute Tribe. Clim. Chang. 2013, 120, 585-599. [CrossRef]

36. Kinney, T. Chasing the wind: Wyoming Supreme Court decision in Big Horn III denies beneficial use for instream flow protection, but empowers state to administer Federal Indian reserved water right awarded to the Wind River Tribes. Nat. Resour. J. 2004, 33, 841-871.

37. Yazzie, M. Unlimited limitations: The Navajos' Winters rights deemed worthless in the 2012 Navajo-Hopi Little Colorado River Settlement. Wicazo Sa Rev. 2013, 28, 26-37. [CrossRef]

38. Safe Water and Waste Disposal Facilities Fact Sheet. Available online: https://www.ihs.gov/newsroom/ factsheets/safewater/ (accessed on 27 July 2016).

39. Ravisankar, V.A.; Seaman, R.; Mirchandani, S.; Arnold, R.G.; Ela, W.P. Solar-driven membrane distillation demonstration in Leupp, Arizona. Environ. Health 2016, 31, 79-83. [CrossRef] [PubMed]

40. Chief, K.; Artiola, J.F.; Beamer, P.; Wilkinson, S.; Maier, R.M.; Rock, C.; Sanchez, C. Understanding the Gold King Mine Spill. Fact Sheet; University of Arizona: Tucson, AZ, USA, 2015.

41. Cozzetto, K.; Chief, K.; Dittmer, K.; Brubaker, M.; Gough, R.; Souza, K.; Ettawageshik, F.; Wotkyns, S.; Opitz-Stapleton, S.; Duren, S.; et al. Climate change impacts on the water resources of American Indians and Alaska Natives in the U.S. Clim. Chang. 2013, 2013. [CrossRef]

42. Brubaker, M.; Berner, J.; Bell, J.; Warren, J.; Rolin, A. Climate Change in Point Hope Alaska: Strategies for Community Health. Available online: http://www.cidrap.umn.edu/sites/default/files/public/php/ 26952/Climate\%20Change\%20HIA\%20Report_Point\%20Hope_0.pdf (accessed on 4 July 2016).

43. Lomawaima, K.T. Tribal sovereigns: Reframing research in American Indian education. Harv. Educ. Rev. 2000, 70, 1-23. [CrossRef]

44. Davis, S.M.; Reid, R. Practicing participatory research in American Indian communities. Am. J. Clin. Nutr. 1999, 69, 755S-759S. [PubMed]

45. Sahota, P.C. Research Regulation in American Indian/Alaska Native communities: A Guide to Reviewing Research Studies. Available online: https://depts.washington.edu/ccph/pdf_files/.pdf (accessed on 27 July 2016).

46. Brugge, D.; Missaghian, M. Protecting the Navajo people through tribal regulation of research. Sci. Eng. Ethics 2006, 12, 491-507. [CrossRef] [PubMed]

47. University of Arizona Native Peoples Technical Assistance Office. Handbook for Research in Indian Country; University of Arizona Press: Tucson, AZ, USA, 2016.

48. Code of Federal Regulations, Title 45, Public Welfare, Department of Health and Human Services, Part 46, Protection of Human Subjects. 2009. Available online: http:/ /www.hhs.gov/ohrp/regulations-and-policy/ regulations /45-cfr-46/ (accessed on 27 July 2016).

49. The Ethics of Traditional Knowledge Exchange in Climate Change Initiatives. Available online: http:// earthzine.org/2015/07/31/the-ethics-of-traditional-knowledge-exchange-in-climate-change-initiatives / (accessed on 4 July 2016).

50. Whyte, K.P.; Brewer, J.P., II; Johnson, J.T. Weaving Indigenous science, protocols and sustainability science. Sustain. Sci. 2015, 11, 25-32. [CrossRef] 
51. Burkhart, B.Y. What coyote and Thales can teach us: An outline of American Indian epistemology. In American Indian Thought: Philosophical Essays; Waters, A., Ed.; Wiley-Blackwell: San Francisco, CA, USA, 2004.

52. Kimmerer, R.W. Braiding Sweetgrass: Indigenous Wisdom, Scientific Knowledge and the Teachings of Plants; Milkweed Editions: Minneapolis, MN, USA, 2015.

53. Whyte, K.P. On the role of traditional ecological knowledge as a collaborative concept: A philosophical study. Ecol. Process. 2013, 2, 1-12. [CrossRef]

54. Hardison, P.; Williams, T. Culture, law, risk and governance: Contexts of traditional knowledge in climate change adaptation. Clim. Chang. 2013, 2013. [CrossRef]

55. Whyte, K.P. What Do Indigenous Knowledges Do for Indigenous Peoples? In Keepers of the Green World: Traditional Ecological Knowledge and Sustainability; Nelson, M.K., Shilling, D., Eds.; Cambridge University Press: Cambridge, UK, 2015.

56. Smith, L.T. Decolonizing Methodologies: Research and Indigenous Peoples; Zed Books: London, UK, 1999.

57. Jasanoff, S.; Wynne, B. Science and decisionmaking. In Human Choice and Climate Change; Rayner, S., Malone, E.L., Eds.; Battelle Press: Columbus, OH, USA, 1998.

58. Dilling, L.; Lemos, M.C. Creating usable science: Opportunities and constraints for climate knowledge use and their implications for science policy. Glob. Environ. Chang. 2011, 21, 680-689. [CrossRef]

59. Lemos, M.C.; Morehouse, B.J. The co-production of science and policy in integrated climate assessments. Glob. Environ. Chang. 2005, 15, 57-68. [CrossRef]

60. Beierle, T.C. The quality of stakeholder-based decisions. Risk Anal. 2002, 22, 739-749. [CrossRef] [PubMed]

61. Nadasdy, P. The anti-politics of TEK: The institutionalization of co-management discourse and practice. Anthropologica 2005, 47, 215-231.

62. Rowe, G.; Frewer, L.J. A typology of public engagement mechanisms. Sci. Technol. Hum. Values 2005, 30, 251-290. [CrossRef]

63. Stern, P.C.; Fireberg, H.V. Understanding Risk: Informing Decisions in a Democratic Society; National Academies Press: Washington, DC, USA, 1996.

64. Ford, J.D.; Stephenson, E.; Willox, A.C.; Edge, V.; Farahbakhsh, K.; Furgal, C.; Harper, S.; Chatwood, S.; Mauro, I.; Pearce, T.; et al. Community-based adaptation research in the Canadian Arctic. Wiley Interdiscip. Rev. Clim. Chang. 2015, 7. [CrossRef]

65. Fisher, P.A.; Ball, T.J. Tribal participatory research: Mechanisms of a collaborative model. Am. J. Community Psychol. 2003, 32, 207-216. [CrossRef] [PubMed]

66. Lewin, K. Action research and minority problems. J. Soc. Issues 1946, 46, 34-46. [CrossRef]

67. Robinson, C.J.; Wallington, T.J. Boundary work: Engaging knowledge systems in comanagement of feral animals on Indigenous lands. Ecol. Soc. 2012, 17. [CrossRef]

68. Bark, R.H.; Garrick, D.E.; Robinson, C.J.; Jackson, S. Adaptive basin governance and the prospects for meeting indigenous water claims. Environ. Sci. Policy 2012, 19, 169-177. [CrossRef]

69. Hill, R.; Grant, C.; George, M.; Robinson, C.J.; Jackson, S.; Abel, N. A typology of indigenous engagement in Australian environmental management: Implications for knowledge integration and social-ecological system sustainability. Ecol. Soc. 2012, 17. [CrossRef]

70. Cronin, A.E.; Ostergren, D.M. Democracy, participation, and Native American tribes in collaborative watershed management. Soc. Nat. Resour. 2007, 20, 527-542. [CrossRef]

71. Biggs, S.D. Resource-Poor Farmer Participation in Research: A Synthesis of Experiences from Nine National Agricultural Research Systems; International Service for National Agricultural Research: The Hague, The Netherlands, 1989; Volume 3, p. 37.

72. Huntington, H.P. We dance around in a ring and suppose: Academic engagement with traditional knowledge. Arct. Anthropol. 2005, 42, 29-32. [CrossRef]

73. Huntington, H.P.; Gearheard, S.; Mahoney, A.R.; Salomon, A.K. Integrating traditional and scientific knowledge through collaborative natural science field research: Identifying elements for success. Arctic 2011, 64, 437-445. [CrossRef]

74. Latulippe, N. Situating the work: A typology of traditional knowledge literature. Altern. Int. J. Indig. Peoples 2015, 11, 118-131.

75. Ferguson, D.B.; Masayesva, A.; Meadow, A.M.; Crimmins, M.A. Rain gauges to range conditions: Developing a local drought information system using locally relevant observations. Weather Clim. Soc. 2016, in press. [CrossRef] 
76. Smith, W.J., Jr.; Liu, Z.; Safi, A.S.; Chief, K. Climate change perception, observation and policy support in rural Nevada: A comparative analysis of Native Americans, non-native ranchers and farmers and mainstream America. Environ. Sci. Policy 2014, 42, 101-122. [CrossRef]

77. Megdal, S.M.; Chief, K.; McLain, J.E. Collaborative Conference Planning and Continuing the Dialogue. Available online: https://wrrc.arizona.edu/Collaborative_Conference_Planning (accessed on 27 July 2016).

78. Mott Lacroix, K.; Xiu, B.; Megdal, S.B. Roadmap for Considering Water for Arizona's Natural Areas. Available online: https://wrrc.arizona.edu/sites/wrrc.arizona.edu/files/RAPIDS/PDF/Roadmap_Complete_2014. pdf (accessed on 27 July 2016).

79. Bureau of Reclamation. Colorado River Basin Water Supply and Demand Study. Available online: http: //www.usbr.gov/lc/region/programs/crbstudy/finalreport/index.html (accessed on 27 July 2016).

(C) 2016 by the authors; licensee MDPI, Basel, Switzerland. This article is an open access article distributed under the terms and conditions of the Creative Commons Attribution (CC-BY) license (http://creativecommons.org/licenses/by/4.0/). 